\title{
Arbeidsvoorwaarden en de gewenste pensioenleeftijd
}

\author{
Marianne van Zwieten, Jan Fekke Ybema \& Goedele Geuskens*
}

In deze studie is nagegaan in hoeverre de leeftijd tot waarop werknemers willen doorwerken (de gewenste pensioenleeftijd) afhankelijk is van de tevredenheid met de arbeidsvoorwaarden die zij hebben. Hiervoor is gebruikgemaakt van de gegevens van het NEA-cohortonderzoek (metingen 2008 en 2009). De resultaten van de longitudinale analyse laten zien dat tevredenheid met arbeidsvoorwaarden die te maken hebben met flexibiliteit (zoals flexibele werktijden en deeltijdwerk) bijdraagt aan een hogere gewenste pensioenleeftijd. Tevens draagt het bij aan het niet weten van de gewenste pensioenleeftijd. Dit betekent dat werknemers die tevreden zijn over flexibiliteit in hun werk vaker dan ontevreden werknemers niet weten tot welke leeftijd zij willen doorwerken, maar als ze het wél weten is de gewenste pensioenleeftijd hoger dan bij ontevreden werknemers. Door de flexibiliteit in het werk (zoals thuiswerkregeling en flexibele werktijden) in samenspraak met en naar tevredenheid van de werknemer in te vullen, kunnen werknemers worden gestimuleerd om langer door te werken.

\section{Inleiding}

In Nederland is sprake van een krimpende en vergrijzende beroepsbevolking (Van Duin \& Garssen, 2010). Dit komt enerzijds door de vergrijzing van de werknemers die zijn geboren tussen ongeveer 1945 en 1955 (de babyboomgeneratie). Anderzijds is er in de laatste decennia sprake van een relatieve daling van het aantal jongeren (Eurostat, 2008; United Nations, 2007). Doordat minder jongeren instromen op de arbeidsmarkt en een groot aantal babyboomers de arbeidsmarkt zal verlaten wordt in de nabije toekomst een tekort aan arbeidskrachten verwacht (European Commission, 2008). Daarbij is de levensverwachting de laatste decennia toegenomen en de verwachting is dat deze trend zich voorlopig doorzet (Actuarieel Genootschap, 2010; Van Duin \& Garssen, 2010). Om het tekort aan arbeidskrachten op te vangen en de welvaartsstaat in de toekomst betaalbaar te houden, is het onder meer van belang dat werknemers zo lang mogelijk blijven werken en niet voortijdig stoppen.

Of werknemers blijven werken hangt samen met verschillende factoren. We maken hierbij onderscheid tussen persoonsgebonden en werkgerelateerde factoren. Deze persoonsgebonden en werkgerelateerde factoren kunnen, al dan niet in samenhang, voor een werknemer de aanleiding zijn om door te gaan of juist eerder te stoppen met werken. Bij persoonsgebonden factoren gaat het bijvoorbeeld

* Marianne van Zwieten, Jan Fekke Ybema en Goedele Geuskens zijn werkzaam bij TNO. Correspondentieadres: Drs. M.H.J. van Zwieten, TNO, Postbus 718, 2130 AS Hoofddorp. Tel.: 0888662704 . 
om de gezondheid van de werknemer, de familiesituatie (de ervaren steun van de partner) of de financiële situatie (vermogen, inkomen partner) die een werknemer kunnen motiveren om al dan niet door te gaan met werken. Zo blijkt dat een slechte gezondheid en een tekort aan fysieke activiteit vroegpensioen voorspellen (Van den Berg, Elders \& Burdorf, 2010). Uit een onderzoek waarin de focus ligt op de houding van werknemers ten aanzien van langer doorwerken, blijkt dat gezondheid een goede voorspeller is van kunnen doorwerken, en in mindere mate van willen doorwerken tot 65 jaar (Ybema, Geuskens \& Oude Hengel, 2009). Verder laat onderzoek van Henkens, Van Dalen en Van Solinge (2009) zien dat een goede vermogenspositie de kans dat langer wordt doorgewerkt vermindert, terwijl een partner die doorwerken aanmoedigt juist een stimulans is om langer door te werken. Werknemers die druk ervaren van hun partner om eerder te stoppen met werken zijn sterker geneigd om eerder dan de officiële pensioenleeftijd te stoppen dan werknemers die deze druk niet ervaren (Van Dam, Van der Vorst \& Van der Heijden, 2009). Naast deze persoonsgebonden factoren spelen ook diverse werkgerelateerde factoren een rol bij het wel of niet (kunnen en willen) doorwerken. Het kan gaan om de inhoud van het werk, maar ook om arbeidsomstandigheden, arbeidsrelaties en arbeidsvoorwaarden. Een recent uitgevoerde review van longitudinale studies laat bijvoorbeeld zien dat hoge fysieke taakeisen, een hoge werkdruk en een lage werktevredenheid vroegpensioen voorspellen (Van den Berg et al., 2010). Uit een studie gericht op de houding ten aanzien van langer doorwerken, komt naar voren dat werknemers die intern ongewenst gedrag (pesten, intimidatie of geweld door collega's of leidinggevende) ervaren niet willen doorwerken tot hun $65^{\mathrm{e}}$ levensjaar (Ybema et al., 2009). Ditzelfde onderzoek wijst uit dat minder sociale steun van de leidinggevende voorspellend is voor het niet kunnen doorwerken tot het $65^{\mathrm{e}}$ jaar.

Veel onderzoek naar langer doorwerken richt zich op arbeidsomstandigheden, terwijl aan de rol van arbeidsvoorwaarden weinig aandacht wordt besteed. Onder arbeidsvoorwaarden verstaan we de voorwaarden waaronder werk wordt verricht, zoals salaris en pensioenregeling maar ook afspraken rondom arbeidstijden (zoals flexibele werktijden) en ontwikkelingsmogelijkheden (zoals scholing en opleiding). Er is wel onderzoek gedaan naar de rol van arbeidsvoorwaarden bij de keuze van gepensioneerden om toch weer aan het werk te gaan (Armstrong-Stassen, 2008) en de mate waarin werkgevers bepaalde arbeidsvoorwaarden implementeren om oudere werknemers aan het werk te houden (Remery, Henkens, Schippers \& Ekamper, 2003). In hoeverre arbeidsvoorwaarden samenhangen met de motivatie van oudere werknemers om door te werken is echter nauwelijks onderzocht. Dit terwijl arbeidsvoorwaarden door werkgevers goed beïnvloedbaar zijn, in tegenstelling tot bijvoorbeeld persoonsgebonden factoren en een deel van de overige werkgerelateerde factoren. In de motivatiepsychologie wordt wel ingegaan op de rol van arbeidsvoorwaarden bij motivatie. Al sinds lange tijd wordt onderscheid gemaakt tussen intrinsieke en extrinsieke motivatie (Deci, 1971). Werknemers kunnen intrinsiek gemotiveerd raken door de inhoud van hun werk, terwijl extrinsieke motivatie kan worden gestimuleerd door bijvoorbeeld goede (secundaire) arbeidsvoorwaarden. Deze extrinsieke motivatie kan volgens de ZelfDeterminatie Theorie (ZDT) autonoom of gecontroleerd zijn. Bij gecontroleerde 
motivatie voeren werknemers hun werk uit om ofwel beloningen te krijgen en positieve gevoelens te ervaren ofwel straffen en negatieve gevoelens te vermijden (Van den Broeck, Vansteenkiste, De Witte, Lens \& Andriessen, 2009). In het geval van extrinsieke autonome motivatie zetten werknemers zich in omdat ze het werk persoonlijk belangrijk of waardevol vinden of omdat het past binnen het eigen waardepatroon. Autonome motivatie gaat samen met vervulling van de psychologische basisbehoeften autonomie, verbondenheid en competentie. Uit onderzoek blijkt dat autonome motivatie bijdraagt aan meer tevredenheid met het werk (Ilardi, Leone, Kasser \& Ryan, 1993) en een verminderde neiging om ontslag te nemen (Vansteenkiste et al., 2007). Met arbeidsvoorwaarden kan een werkgever beide vormen van motivatie (autonoom en gecontroleerd) versterken. De autonome motivatie kan bijvoorbeeld worden gestimuleerd door groei en ontwikkeling te bevorderen door het bieden van scholing en opleiding. Daarnaast kan de gecontroleerde motivatie worden versterkt door financiële stimulansen (zoals een bonusregeling). Op basis van de Zelf-Determinatie Theorie lijken arbeidsvoorwaarden langer doorwerken te kunnen bevorderen. In deze motivatietheorie wordt echter niet ingegaan op de rol van leeftijd. Mogelijk werken voor oudere werknemers andere arbeidsvoorwaarden motiverend dan voor jongeren. Zo stelt de theorie van Selectie, Optimalisatie en Compensatie dat mensen zich naarmate zij ouder zijn meer richten op het behouden van het huidige niveau van functioneren en het reguleren van verlies en minder op groei (Baltes, Staudinger \& Lindenberger, 1999). Een onderzoek van Kooij (2009) laat daarentegen zien dat zowel arbeidsvoorwaarden die zich richten op groei (zoals loopbaanontwikkeling en training) als arbeidsvoorwaarden die gericht zijn op het reguleren van verlies (zoals horizontale baanverandering en extra verlof) positief samenhangen met de motivatie van oudere werknemers om door te werken. Er is echter geen longitudinaal onderzoek bekend waarin de rol van arbeidsvoorwaarden bij langer doorwerken door oudere werknemers is onderzocht.

Om oudere werknemers te kunnen stimuleren om langer door te werken is meer inzicht nodig in de rol van arbeidsvoorwaarden bij langer doorwerken. In het huidige longitudinale onderzoek is nagegaan in hoeverre de leeftijd tot waarop werknemers willen doorwerken (de gewenste pensioenleeftijd) afhankelijk is van de tevredenheid van werknemers met de arbeidsvoorwaarden die zij hebben. We verwachten op basis van de literatuur dat gunstige arbeidsvoorwaarden het voor een werknemer aantrekkelijk kunnen maken om te blijven werken. De algemene hypothese luidt dat een hogere tevredenheid van werknemers met arbeidsvoorwaarden leidt tot een hogere gewenste pensioenleeftijd.

Hypothese 1: Een hogere tevredenheid met arbeidsvoorwaarden leidt tot een hogere gewenste pensioenleeftijd.

Op basis van onderzoek van Henkens et al. (2009) kan voor arbeidsvoorwaarden die te maken hebben met het inkomen (salaris en pensioenregeling) ook een alternatieve (omgekeerde) hypothese worden geformuleerd. Werknemers die tevreden zijn met hun salaris en met hun pensioenregeling zullen doorgaans meer financiële mogelijkheden hebben om eerder uit te treden dan werknemers die 
ontevreden zijn met hun salaris en pensioenregeling. Dit zal er wellicht toe leiden dat werknemers die een goed pensioen in het vooruitzicht hebben of een aanzienlijk salaris ontvangen, eerder willen stoppen met werken omdat er minder financiële noodzaak is om door te werken.

Hypothese 2: Een hogere tevredenheid met het salaris en de pensioenregeling leidt tot een lagere gewenste pensioenleeftijd.

\section{Methode}

\subsection{Onderzoeksopzet en steekproef}

Dit onderzoek maakt gebruik van de gegevens van het NEA-cohortonderzoek (Koppes, De Vroome \& Van den Bossche, in bewerking). Het NEA-cohortonderzoek is een longitudinaal onderzoek op basis van de Nationale Enquête Arbeidsomstandigheden (NEA) 2007 (Van den Bossche, Koppes, Granzier, De Vroome \& Smulders, 2008). De NEA is een grootschalige enquête onder werknemers in Nederland waarin onder meer wordt gevraagd naar arbeidsomstandigheden, arbeidsinhoud, arbeidsverhoudingen en arbeidsvoorwaarden. Het onderzoek wordt uitgevoerd door TNO en het CBS. Aan de NEA 2007 hebben 22.759 respondenten deelgenomen. Van deze respondenten hebben 19.260 personen (84,6\%) aangegeven mee te willen werken aan vervolgonderzoek. $\mathrm{Zij}$ zijn voor het cohortonderzoek in 2008 en 2009 opnieuw bevraagd met eenzelfde enquête. In 2008 zijn 10.328 (54\%) bruikbare vervolgvragenlijsten retour ontvangen, terwijl het in 2009 om 7.860 bruikbare vervolgvragenlijsten gaat. Het NEA-cohort biedt uitgebreide mogelijkheden tot kennisontwikkeling over relaties in de tijd tussen alle aspecten die aan bod komen in de NEA. Het huidige onderzoek is gebaseerd op de gegevens van oudere werknemers (respondenten van 45 tot en met 64 jaar ten tijde van de meting van 2008) die in zowel 2008 als 2009 de vragenlijst hebben ingevuld. Het gaat om 4.354 werknemers. De meting in 2007 wordt buiten beschouwing gelaten omdat daarin niet wordt gevraagd naar de gewenste pensioenleeftijd. De gehanteerde leeftijdsgrens van 45 jaar komt overeen met de definitie van oudere werknemers door de WHO (1993).

\subsection{Onderzoeksvariabelen}

Demografische variabelen. In de NEA-vragenlijst is respondenten gevraagd naar geslacht ( 1 = man, 2 = vrouw), geboortejaar en opleiding ( 1 = laag, 2 = midden, 3 = hoog). Bij laagopgeleiden gaat het om werknemers die geen opleiding hebben gevolgd of afgemaakt, alleen basisonderwijs hebben genoten, of lager of middelbaar voortgezet onderwijs (mavo/vbo) hebben gevolgd. Middelbaar opgeleiden zijn werknemers die hoger voortgezet onderwijs (havo/vwo) of middelbaar beroepsonderwijs (mbo) hebben afgerond. Werknemers die hoger beroepsonderwijs of wetenschappelijk onderwijs hebben voltooid vallen in de categorie hoogopgeleiden. De leeftijd van de respondenten ten tijde van de 2008 meting is afgeleid van het geboortejaar. 

rotatie

\begin{tabular}{llll}
\hline $\begin{array}{l}\text { Kunt u met een rapportcijfer aangeven } \\
\text { hoe tevreden u bent over de volgende } \\
\text { zaken?(I=zeer ontevreden tot I } \\
\text { tevredeer }\end{array}$ & $\begin{array}{l}\text { Ontwikkelmo- } \\
\text { gelijkheden }\end{array}$ & Flexibiliteit Geldzaken \\
\hline Salaris & .28 & .75 & \\
Resultaatgerichte beloning/prestatiebeloning & .35 & .00 & .66 \\
Pensioenregeling & .07 & .21 & .7 I \\
Reiskostenvergoeding & .08 & .19 & .63 \\
Mogelijkheden om zelf arbeidsvoorwaarden & .44 & .33 & .41 \\
samen te stellen & & & \\
Functioneringsgesprekken & .76 & .20 & .16 \\
Promotie- en loopbaanmogelijkheden & .82 & .13 & .23 \\
Scholings- en opleidingsmogelijkheden & .77 & .19 & .17 \\
Mogelijkheden om in deeltijd te werken & .13 & .75 & .03 \\
Flexibele werktijden & .16 & .83 & .17 \\
Thuiswerkregeling & .18 & .68 & .13 \\
Verlof- en vakantiemogelijkheden & .25 & .54 & .28 \\
Overlegmogelijkheden & .59 & .42 & .20 \\
\hline
\end{tabular}

Arbeidsvoorwaarden. In de NEA-cohortstudie is respondenten gevraagd een rapportcijfer ( 1 = zeer ontevreden tot $10=$ zeer tevreden) te geven voor de tevredenheid met 13 aspecten van hun huidige baan. Ook is er per vraag de antwoordmogelijkheid 'weet niet/niet van toepassing'. Het betreft een bewerking van vragen uit de monitor Arbeidsvoorwaarden en arbeidsverhoudingen op OndernemingsNiveau (de AVON-monitor; Ten Have, Oeij \& Kraan, 2007) en de TNO Arbeidssituatie Survey (TAS; Smulders, Andries \& Otten, 2001). Bij de aspecten 'mogelijkheden om zelf arbeidsvoorwaarden samen te stellen', 'reiskostenvergoeding' en 'resultaatgerichte beloning/prestatiebeloning' heeft ongeveer een derde van de respondenten geen rapportcijfer gegeven. Bij het aspect 'thuiswerkregeling' is dat het geval bij ongeveer de helft. Dit zijn aspecten die niet in alle bedrijven aanwezig zullen zijn en daardoor relatief vaak niet van toepassing zullen zijn. Er is onderzocht of de 13 vragen zijn onder te brengen in schalen. Hiertoe is op de correlatiematrix van de vragen over tevredenheid met 13 aspecten van de huidige baan een principale componentenanalyse (PCA) uitgevoerd met een orthogonale rotatie (varimax) van de factoren. Aangezien het aantal ontbrekende gegevens bij factoranalyse niet groter mag zijn dan 5\% (Uberla, 1971), zijn bij de factoranalyse de missende waarden (optie 'weet niet/n.v.t.') vervangen door de gemiddelde waarden. Drie componenten hebben een eigenwaarde groter dan 1, het Kaiser-criterium (Kaiser, 1960). De factoranalyse resulteert in drie factoren die samen verantwoordelijk zijn voor $58 \%$ van de totale variantie. De orthogonale rotatie van de factoren mondt uit in de factorstructuur die staat weergegeven in tabel 1. 
De drie factoren zijn geïdentificeerd als geldzaken, ontwikkelmogelijkheden en flexibiliteit. Daarna is nagegaan of de vragen die laden op eenzelfde factor samen een voldoende betrouwbare schaal vormen. De vraag 'mogelijkheden om zelf arbeidsvoorwaarden samen te stellen' laadt sterk op meer dan één factor en is niet meegenomen. De betrouwbaarheid van de drie schalen is goed: de Cronbach's alpha van geldzaken is .78, van ontwikkelmogelijkheden .84 en van flexibiliteit .80. Vervolgens zijn de drie schalen geconstrueerd waarbij telkens het gemiddelde van de onderliggende vragen is genomen, mits de respondent drie of meer van de vier vragen heeft beantwoord met een rapportcijfer. Om alle beschikbare informatie te behouden is voor elke schaal tevens een dummyvariabele aangemaakt die aangeeft of de betreffende schaal een valide (0) of missende waarde (1) heeft. Van een missende waarde is sprake wanneer op twee of meer vragen van een schaal 'weet niet/n.v.t.' is geantwoord. Het percentage missende waarden op de drie schaalvariabelen is $17 \%$ voor geldzaken, $17 \%$ voor ontwikkelmogelijkheden en $30 \%$ voor flexibiliteit (zie tabel 2). Doordat in de analyse (met de dummyvariabele) wordt gecontroleerd voor het hebben van een valide of missende waarde op de schaal, maakt het voor de analyse niet uit welke (constante) waarde aan de schaal wordt toegekend in het geval van een missende waarde. Bij een missende waarde op een schaal krijgt de respondent het algemene gemiddelde op de betreffende schaal als schaalwaarde toegewezen (Cohen \& Cohen, 1983). Toekenning van het algemene gemiddelde heeft als voordeel dat de correlaties tussen de schaalwaarde en de dummyvariabele 0 is en de overige correlaties met de schaal vrijwel ongewijzigd blijven.

Gewenste pensioenleeftijd. In de NEA-vragenlijst is werknemers gevraagd tot welke leeftijd zij willen doorwerken. Deze open vraag is zowel in 2008 als in 2009 gesteld. Daarnaast hebben respondenten de mogelijkheid 'weet niet' aan te kruisen. Bij de variabele 'gewenste pensioenleeftijd' is voor de eerste meting (2008) de gemiddelde waarde ingevuld indien respondenten de optie 'weet niet' hebben aangekruist. Daarnaast is voor beide metingen (2008 en 2009) een dummyvariabele aangemaakt waarbij 0 een valide waarde betreft en 1 de optie 'weet niet'. Ook hierbij wordt dus alle beschikbare informatie gebruikt in de analyse.

\subsection{Analyses}

De gegevens zijn geanalyseerd met SPSS 17.0 voor Windows. Allereerst zijn beschrijvende analyses uitgevoerd op de gegevens van 2008 waarbij onder meer is gekeken naar de gemiddelde gewenste pensioenleeftijd van de werknemers ouder dan 45 jaar. De samenhang tussen de gewenste pensioenleeftijd en geslacht, opleiding en leeftijd van de werknemer is onderzocht door cross-sectionele analyses. Met univariate variantieanalyse is getoetst of de gemiddelde gewenste pensioenleeftijd in 2008 verschilt voor mannen en vrouwen en voor laag-, middelbaar en hoogopgeleide werknemers. Vervolgens is een longitudinale hiërarchische regressieanalyse uitgevoerd om zicht te krijgen op de effecten van de tevredenheid met arbeidsvoorwaarden (in 2008) op de gewenste pensioenleeftijd (in 2009). In de eerste stap van de regressieanalyse zijn de gewenste pensioenleeftijd in 2008 en de dummyvariabele 'weet niet' (2008) ingevoerd. Er wordt gecorri- 
geerd voor de gewenste pensioenleeftijd in 2008 om meer zekerheid te krijgen over de richting van causaliteit: de bijdrage van de voorspellers aan willen doorwerken kan worden beschouwd als een bijdrage aan de verandering in willen doorwerken tussen 2008 en 2009. De dummyvariabele 'weet niet' is opgenomen om te corrigeren voor het eventuele effect van het wel of niet hebben van een valide waarde op de gewenste pensioenleeftijd 2008. Ofwel, verschilt de in 2009 gewenste pensioenleeftijd van werknemers die in 2008 weten tot welke leeftijd zij willen doorwerken van die van werknemers die dat in 2008 niet weten? Daarna zijn in de tweede stap van de regressie de persoonskenmerken toegevoegd. De persoonskenmerken waarvoor wordt gecontroleerd zijn geslacht, leeftijd en opleidingsniveau. Vervolgens zijn in de derde stap de drie arbeidsvoorwaardenschalen (tevredenheid met geldzaken, ontwikkelmogelijkheden en flexibiliteit) en de drie bijbehorende dummyvariabelen 'weet niet/n.v.t.' ingevoerd. Door het opnemen van deze drie dummyvariabelen wordt nagegaan of het wel of niet hebben van een valide waarde op de schalen effect heeft op de gewenste pensioenleeftijd in 2009. Ofwel, verschilt de gewenste pensioenleeftijd van werknemers die niet weten of ze tevreden zijn of waarbij bepaalde arbeidsvoorwaarden niet van toepassing zijn van de gewenste pensioenleeftijd van werknemers die wel met een rapportcijfer hun tevredenheid aangeven? In deze longitudinale hiërarchische regressieanalyse is de gewenste pensioenleeftijd op de meting van 2009 de afhankelijke variabele.

Ten slotte is een longitudinale logistische regressieanalyse uitgevoerd van het wel of niet weten van de gewenste pensioenleeftijd (in 2009) op de tevredenheid met arbeidsvoorwaarden (in 2008). Bij deze analyse zijn dezelfde variabelen stapsgewijs ingevoerd als bij de hiërarchische regressieanalyse. De gebruikte maat voor samenhang is de odds ratio (OR) en het $95 \%$ betrouwbaarheidsinterval.

\section{Resultaten}

\subsection{Beschrijvende analyses}

De gemiddelde waarden, standaarddeviaties en intercorrelaties van de onderzoeksvariabelen zijn weergegeven in tabel 2. De gemiddelde leeftijd van de respondenten bedraagt ten tijde van de meting in 200853 jaar. Van de respondenten is $54 \%$ man. Het opleidingsniveau is laag voor $24 \%$ van de respondenten, middelbaar voor $35 \%$ en hoog voor $41 \%$ van de respondenten. Uit de tabel blijkt dat de gewenste pensioenleeftijd in 2008 sterk samenhangt met de gewenste pensioenleeftijd in 2009. De gemiddelde gewenste pensioenleeftijd van de werknemers van 45 jaar en ouder is in 2008 en 2009 nagenoeg gelijk (respectievelijk 62,5 jaar en 62,6 jaar). Ook de drie variabelen voor tevredenheid met arbeidsvoorwaarden hangen sterk samen. 


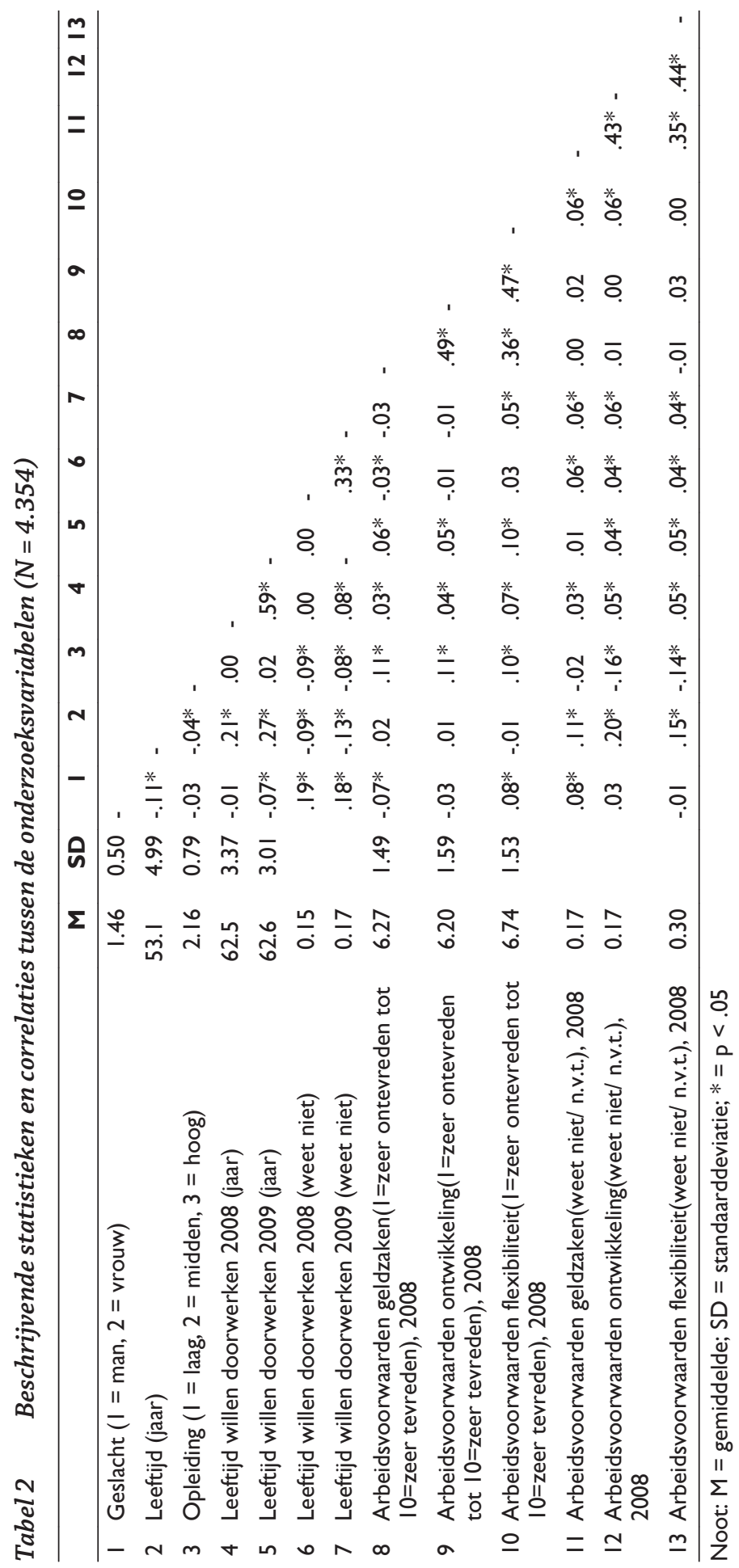




\subsection{Samenhang gewenste pensioenleeftijd en geslacht, opleiding en leeftijd}

Uit de variantieanalyse blijkt dat de gewenste pensioenleeftijd in 2008 voor mannen $(62,6$ jaar) en vrouwen $(62,5$ jaar) niet verschilt, $F(1,3490)=0.16$, ns. Ook bij opleidingsniveau is er geen verschil in leeftijd tot waarop werknemers willen doorwerken (laag: 62,6 jaar, middelbaar: 62,3 jaar, hoog: 62,6 jaar), $F(2,3490)=$ 2.74, ns. Wel is er sprake van een interactie-effect tussen geslacht en opleiding, $F(2,3490)=5.75, p<.01$. De relatie tussen opleiding en gewenste pensioenleeftijd is dus verschillend voor mannen en vrouwen (zie tabel 3). Bij vrouwen blijken laagopgeleiden een hogere gewenste pensioenleeftijd te hebben dan middelbaar en hoogopgeleiden (Bonferroni $p<.05$ ). Bij mannen zijn het juist de hoogopgeleiden die een hogere gewenste pensioenleeftijd hebben dan de middelbaar en laagopgeleiden (Bonferroni $p<.05$ ). De interactie tussen geslacht en opleiding blijkt geen significante bijdrage te leveren aan het model en wordt verder buiten beschouwing gelaten. Voor mannen en vrouwen en voor laag-, middelbaar en hoogopgeleide werknemers is tevens nagegaan of het percentage dat niet weet wat de gewenste pensioenleeftijd is verschilt. In tabel 3 zijn de percentages respondenten die niet weten tot welke leeftijd zij willen doorwerken weergegeven. De analyse levert een hoofdeffect op van geslacht op het niet weten van de gewenste pensioenleeftijd, $F(1,4279)=164.92, p<.001$. Vrouwen $(23 \%)$ blijken significant vaker niet te weten tot welke leeftijd zij willen doorwerken dan mannen $(9 \%)$. Ook voor opleiding is een hoofdeffect gevonden op het niet weten van de gewenste pensioenleeftijd, $F(2,4279)=15.39, p<.001$. Laagopgeleide werknemers $(20 \%)$ weten significant vaker dan hoogopgeleide werknemers (12\%) niet tot welke leeftijd zij willen doorwerken.

De leeftijd van de werknemers laat een sterke relatie zien met de gewenste pensioenleeftijd: hoe ouder de werknemer, hoe hoger de gewenste pensioenleeftijd (figuur 1). Verder blijkt dat er sprake is van een kromlijnig verband tussen leeftijd en de gewenste pensioenleeftijd: naarmate werknemers ouder zijn, is het verband tussen de leeftijd en de gewenste pensioenleeftijd sterker. Waarschijnlijk is dit het gevolg van een selectie-effect: Oudere werknemers die eerder wílden stoppen zíjn vaak ook gestopt en zitten dus niet meer in de steekproef. Dit selectie-effect treedt vooral op bij 60-plussers omdat zij vaker dan hun jongere collega's in de gelegenheid zijn om te stoppen met werken als ze dat willen. Gezien dit gevonden kromlijnige verband tussen leeftijd en de gewenste pensioenleeftijd, is het van belang om leeftijd ook als gekwadrateerde variabele mee te nemen in de longitudinale analyses. Ten slotte blijkt dat jongere werknemers vaker dan oudere werknemers niet weten tot welke leeftijd zij willen doorwerken.

\subsection{Effecten van arbeidsvoorwaarden op de gewenste pensioenleeftijd}

De algemene hypothese (H1) dat tevredenheid met arbeidsvoorwaarden bijdraagt aan een hogere gewenste pensioenleeftijd en de alternatieve hypothese dat tevredenheid met geldzaken bijdraagt aan een lagere gewenste pensioenleeftijd (H2) zijn onderzocht met een longitudinale hiërarchische regressieanalyse van de gewenste pensioenleeftijd van werknemers in 2009. De resultaten staan weerge- 
Tabel 3 Gewenste pensioenleeftijd 2008 naar geslacht en opleiding

\begin{tabular}{lllll}
\hline & $\begin{array}{l}\text { Man } \\
\text { Gewenste pensi- } \\
\text { oenleeftijd(in } \\
\text { jaren) }\end{array}$ & $\begin{array}{l}\text { Gewenste pensi- } \\
\text { oenleeftijd(weet } \\
\text { niet) }\end{array}$ & $\begin{array}{l}\text { Vrouw } \\
\text { Gewenste pensi- } \\
\text { oenleeftijd(in } \\
\text { jaren) }\end{array}$ & $\begin{array}{l}\text { Gewenste pensi- } \\
\text { oenleeftijd(weet } \\
\text { niet) }\end{array}$ \\
\hline $\begin{array}{llll}\text { Opleiding } \\
\text { Laag }\end{array}$ & 62.4 & $12 \%$ & 63.0 & $28 \%$ \\
Midden & 62.4 & $8 \%$ & 62.3 & $24 \%$ \\
Hoog & 62.8 & $7 \%$ & 62.4 & $18 \%$ \\
Totaal & 62.6 & $9 \%$ & 62.5 & $23 \%$ \\
\hline
\end{tabular}

Figuur 1 Gewenste pensioenleeftijd naar leeftijd

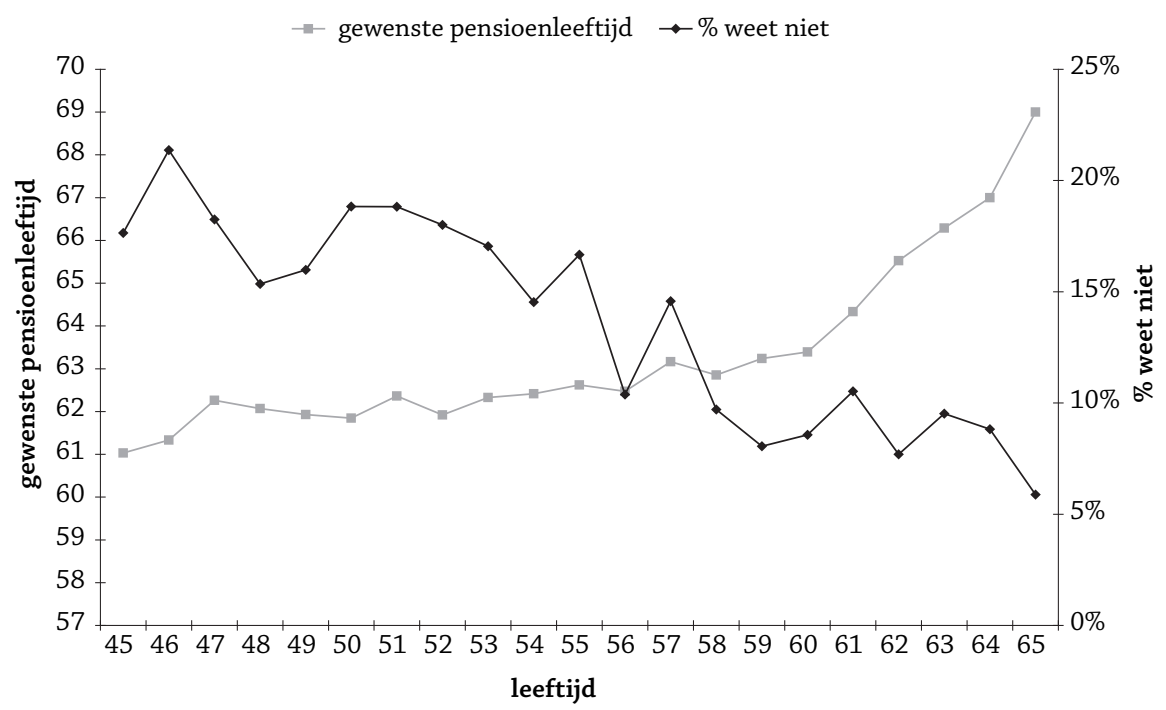

geven in tabel 4. Uit de eerste stap van de regressieanalyse blijkt dat de gewenste pensioenleeftijd in 2008 sterk van invloed is op de gewenste pensioenleeftijd in 2009. Werknemers met een hoge gewenste pensioenleeftijd in 2008 hebben doorgaans ook een hoge gewenste pensioenleeftijd in 2009. De tweede stap wijst uit dat persoonskenmerken bijdragen aan de regressie van de gewenste pensioenleeftijd. Zowel leeftijd als kwadratische leeftijd levert een significante bijdrage. Naarmate werknemers ouder zijn, willen zij tot op een latere leeftijd doorwerken. Ook geslacht levert een significante bijdrage aan de gewenste pensioenleeftijd. Na correctie voor de gewenste pensioenleeftijd in 2008 blijkt dat mannen in 2009 vaker langer willen doorwerken en vrouwen vaker eerder willen stoppen. In de derde stap zijn de drie arbeidsvoorwaardenschalen (tevredenheid met geldzaken, ontwikkelmogelijkheden en flexibiliteit) en de drie bijbehorende dummyvariabelen 'weet niet/ n.v.t.' ingevoerd. In de voorspelling van de gewenste pensioenleeftijd 
Tabel 4 Regressie van de gewenste pensioenleeftijd (2009), met ongestandaardiseerde regressiegewichten (b)

\begin{tabular}{llll}
\hline & Stap I & Stap 2 & Stap 3 \\
\hline Gewenste pensioenleeftijd 2008 & $.542^{* * *}$ & $.505^{* * *}$ & .50 I*** $^{*}$ \\
Gewenste pensioenleeftijd (weet niet) 2008 & -.088 & .057 & .053 \\
Leeftijd & & $.082^{* * *}$ & $.082^{* * *}$ \\
Gekwadrateerde leeftijd & $.008^{* * *}$ & $.008^{* * *}$ \\
Geslacht & $-.283^{* *}$ & $-.294^{* *}$ \\
Opleiding (referentie = Laag) & & \\
$\quad$ Midden & -.047 & -.055 \\
$\quad$ Hoog & .170 & .131 \\
Tevredenheid met geldzaken & & .034 \\
Tevredenheid met ontwikkelmogelijkheden & & -.011 \\
Tevredenheid met flexibiliteit & & $.086^{* * *}$ \\
Tevredenheid met geldzaken (weet niet/niet van & & -.053 \\
toepassing) & & \\
Tevredenheid met ontwikkelmogelijkheden & & -.005 \\
(weet niet/niet van toepassing) & & .057 \\
Tevredenheid met flexibiliteit (weet niet/niet & & \\
van toepassing) & & & \\
\hline
\end{tabular}

Noot: $R^{2}=.342$ voor stap I, $\Delta R^{2}=.025$ voor stap $2(p<.00 \mathrm{I}), \Delta R^{2}=.003$ voor stap $3(p<.05)$; $* * p<.01$; *** $p<.00$ I

blijkt de tevredenheid met arbeidsvoorwaarden $0,3 \%$ verklaarde variantie toe te voegen. Alleen tevredenheid met de flexibiliteit levert een significante bijdrage. Deze derde stap laat, in overeenstemming met de eerste hypothese, zien dat tevredenheid met flexibiliteit in het werk bijdraagt aan een hogere gewenste pensioenleeftijd. De tevredenheid met geldzaken en ontwikkelmogelijkheden dragen niet bij aan een hogere of lagere gewenste pensioenleeftijd. Het totale percentage verklaarde variantie van de gewenste pensioenleeftijd komt op 37\%. 


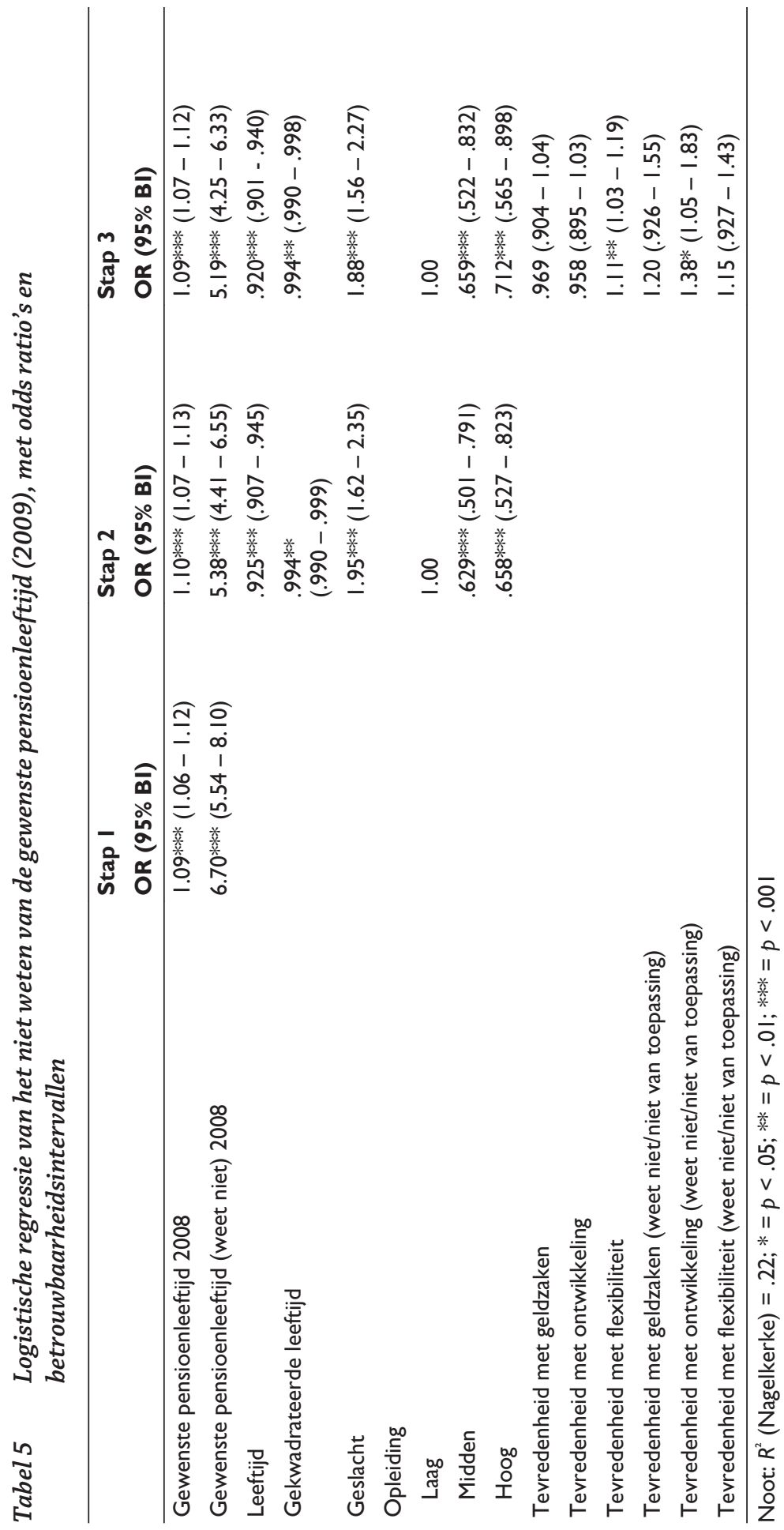


Vervolgens is met een longitudinale logistische regressieanalyse de relatie onderzocht tussen tevredenheid met arbeidsvoorwaarden en de onzekerheid over de gewenste pensioenleeftijd. De eerste stap wijst uit dat het niet weten van de gewenste pensioenleeftijd in 2008 sterk van invloed is op het niet weten van de gewenste pensioenleeftijd in 2009 (zie tabel 5). Werknemers die in 2008 niet weten tot welke leeftijd zij willen doorwerken, weten het in 2009 veelal ook niet. Uit de tweede stap van de regressieanalyse blijkt dat zowel leeftijd, kwadratische leeftijd, geslacht als opleiding een significante bijdrage leveren. Hoe ouder werknemers zijn, hoe vaker zij weten tot welke leeftijd zij willen doorwerken. Daarnaast weten vrouwen en laagopgeleiden vaker niet tot welke leeftijd zij willen doorwerken. Ten slotte zijn in de derde stap de drie arbeidsvoorwaardenschalen (tevredenheid met geldzaken, ontwikkelmogelijkheden en flexibiliteit) en de drie bijbehorende dummyvariabelen 'weet niet/n.v.t.' ingevoerd. Tevredenheid met de flexibiliteit levert een significante bijdrage. Hoe hoger de tevredenheid met flexibiliteit in het werk, hoe vaker werknemers niet weten tot welke leeftijd zij willen doorwerken. Verder komt uit de derde stap naar voren dat werknemers die geen rapportcijfer hebben gegeven voor hun tevredenheid met ontwikkelmogelijkheden (omdat zij het niet weten of omdat het niet van toepassing is) vaker niet weten tot welke leeftijd zij willen doorwerken.

\section{Discussie}

In het huidige onderzoek is nagegaan in hoeverre de gewenste pensioenleeftijd afhankelijk is van de tevredenheid van werknemers over de arbeidsvoorwaarden die zij hebben. Hiervoor is gebruikgemaakt van de gegevens van oudere werknemers in het NEA-cohortonderzoek (metingen 2008 en 2009). De resultaten laten zien dat tevredenheid met flexibiliteit in het werk bijdraagt aan een hogere gewenste pensioenleeftijd. Dit is in overeenstemming met de eerste hypothese. Vervolgens wijzen de resultaten uit dat tevredenheid met flexibiliteit in het werk ook bijdraagt aan het niet weten van de gewenste pensioenleeftijd. Hoe hoger de tevredenheid van werknemers met hun arbeidsvoorwaarden die betrekking hebben op flexibiliteit, hoe vaker zij niet weten tot welke leeftijd zij willen doorwerken. Dit betekent dat werknemers die tevreden zijn met de flexibiliteit in hun werk vaker niet weten tot welke leeftijd zij willen doorwerken dan ontevreden medewerkers, maar als ze het wél weten is de gewenste pensioenleeftijd hoger dan bij ontevreden werknemers.

Uit de resultaten blijkt dus dat tevredenheid van oudere werknemers over de mogelijkheden om in deeltijd te werken, flexibele werktijden, thuiswerkregeling en verlof- en vakantiemogelijkheden ertoe leidt dat zij langer willen doorwerken. Een mogelijke verklaring is dat bij het ouder worden de aandacht voor behoud van functioneren en het reguleren van verlies toeneemt (Baltes et al., 1999). De arbeidsvoorwaarden die gaan over flexibiliteit zijn hierop gericht. Deze arbeidsvoorwaarden maken het oudere werknemers mogelijk om hun werk (op hetzelfde niveau) te blijven uitvoeren ondanks verlies en veranderende omstandigheden. Hiermee hangt samen dat een werknemer in verschillende fasen van zijn leven en 
loopbaan verschillende behoeften heeft. Dit komt door de steeds veranderende situatie waarin de werknemer zich bevindt. Zo verschuift in de laatste fase van de loopbaan bij veel werknemers het accent van werk naar gezin en familie (Henkens \& Van Solinge, 2003). Verder krijgen oudere werknemers (vooral vrouwen tussen 45 en 65 jaar) vaak te maken met mantelzorg voor (schoon)ouders of partner (De Boer, Broese van Groenou \& Timmermans, 2009). Dit vraagt tijd en aandacht. Flexibele werktijden of deeltijdwerk kunnen dan uitkomst bieden waardoor een werknemer kan blijven werken. Een gerelateerde verklaring voor de invloed van tevredenheid met flexibiliteit in het werk is dat voordelen van eerder stoppen met werken vooral zijn terug te voeren op de begrippen vrijheid en tijd. Een onderzoek van Van der Boom en Adams (2006) laat zien dat werkende 45-plussers verwachten dat na het pensioen vooral de tijd voor hobby's en reizen verbetert. Datzelfde onderzoek laat zien dat meer vrije tijd de belangrijkste reden was voor vervroegd gepensioneerden om te stoppen met werken. Als een oudere werknemer echter zeer tevreden is over de flexibiliteit (flexibele werktijden, de mogelijkheid tot deeltijdwerk en thuiswerken) in zijn huidige baan dan is de ervaren winst van eerder stoppen mogelijk minder groot.

Uit de resultaten blijkt dat werknemers die tevreden zijn met de flexibiliteit in hun werk vaker niet weten tot welke leeftijd zij willen blijven werken. Wellicht laat een werknemer die tevreden is over de flexibiliteit in het werk het meer open tot welke leeftijd hij blijft werken, terwijl een werknemer die ontevreden is met de flexibiliteit uitgesproken gedachten heeft over stoppen met werken.

Het huidige onderzoek wijst verder uit dat tevredenheid met geldzaken en ontwikkelmogelijkheden er niet aan bijdragen dat een oudere werknemer langer wil doorwerken. De eerste hypothese die stelt dat een hogere tevredenheid met arbeidsvoorwaarden leidt tot een hogere gewenste pensioenleeftijd geldt dus niet voor alle soorten arbeidsvoorwaarden. De drie arbeidsvoorwaardenschalen (flexibiliteit, ontwikkelmogelijkheden en geldzaken) hangen echter sterk samen. Tevredenheid met flexibiliteit in het werk is voor langer doorwerken blijkbaar belangrijker dan tevredenheid met geldzaken of ontwikkelmogelijkheden. Een andere mogelijke verklaring voor het feit dat tevredenheid met ontwikkelmogelijkheden niet bijdraagt aan langer willen doorwerken is dat deze arbeidsvoorwaarden (zoals promotie- en loopbaanmogelijkheden en scholings- en opleidingsmogelijkheden) vooral zijn gericht op groei. Groeimotieven nemen volgens de theorie van Selectie, Optimalisatie en Compensatie af als mensen ouder worden. Verder wordt de tweede hypothese die luidt dat een hogere tevredenheid met salaris en pensioenregeling leidt tot een lagere gewenste pensioenleeftijd niet bevestigd. Het kan zijn dat de tevredenheid met salaris en pensioenregeling twee tegengestelde effecten heeft, waardoor geldzaken netto niet bijdragen aan de gewenste pensioenleeftijd. Het is ook mogelijk dat het betrekken van de gehele financiële situatie van een werknemer (vermogenspositie, schulden, inkomen van gezinsleden) meer inzicht biedt in de effecten van arbeidsvoorwaarden zoals salaris en pensioenregeling op de gewenste pensioenleeftijd. Zo laat onderzoek van Henkens et al. (2009) zien dat de belangstelling voor langer doorwerken minder groot is naarmate de werknemer meer vermogend is en naarmate er meer inkomen door anderen in het huishouden wordt ingebracht. Volgens Ruhm (1989) betrekken werknemers in 
hun beslissing om eerder te stoppen niet alleen hun eigen inkomen, maar ook het inkomen van hun partner, spaartegoeden en erfenissen.

In bedrijven zijn er diverse mogelijkheden om langer doorwerken te stimuleren. Dit kan bijvoorbeeld door het bieden van ontwikkelmogelijkheden, financiële stimulansen, of ontziemaatregelen (zoals extra verlof, deeltijdpensioen). Een belangrijke implicatie van het huidige onderzoek voor de praktijk is dat de werkgever de mogelijkheid heeft de werknemer te stimuleren langer door te werken door het bieden van flexibiliteit. Door de arbeidsvoorwaarden die te maken hebben met flexibiliteit in samenspraak met en naar tevredenheid van de werknemer in te vullen zullen werknemers naar verwachting langer willen doorwerken. Hierbij is maatwerk van belang, zoals de mogelijkheid om thuis te werken of zeggenschap over de indeling van werktijden. Waar voor de een een extra vrije dag per week uitkomst biedt, is het voor een ander voldoende als er flexibel verlof opgenomen kan worden.

Een sterk punt van deze studie is dat gebruik wordt gemaakt van longitudinale gegevens. De longitudinale effecten van arbeidsvoorwaarden kunnen met meer zekerheid causaal worden geïnterpreteerd doordat wordt gecorrigeerd voor de gewenste pensioenleeftijd in 2008. Bij de huidige studie zijn ook enkele kanttekeningen te plaatsen. $Z_{o}$ is uitgegaan van de tevredenheid van werknemers met arbeidsvoorwaarden. In toekomstig onderzoek zou het interessant zijn om meer informatie te hebben over de inrichting (de aanwezigheid en invulling) van de arbeidsvoorwaarden. Met deze kennis kan een werkgever mogelijk nog beter voldoen aan de wensen van de werknemer. Een andere kanttekening is het hoge percentage werknemers dat de antwoordmogelijkheid 'weet niet/niet van toepassing' heeft aangevinkt bij de vragen naar tevredenheid met arbeidsvoorwaarden. Deze antwoordoptie kan op verschillende manieren worden geduid. Het kan zijn dat de betreffende arbeidsvoorwaarde niet voorkomt in het werk van de werknemer, of dat de werknemer niet weet wat hij van de invulling ervan vindt. Het kan ook zijn dat de werknemer niet weet hoe deze arbeidsvoorwaarde in zijn werk wordt ingevuld.

Ten slotte is het goed om stil te staan bij de grootte van het effect van tevredenheid met flexibele arbeidsvoorwaarden op de gewenste pensioenleeftijd. Dit lijkt een klein effect te zijn, dat slechts $0,3 \%$ van de variantie in gewenste pensioenleeftijd verklaart. Hierbij is het echter van belang om te bedenken dat dit effect is gecorrigeerd voor de gewenste pensioenleeftijd een jaar eerder. Doordat de gewenste pensioenleeftijd een behoorlijke stabiliteit kent, is het te verwachten effect van andere variabelen klein. Het feit dat we desondanks het voorspelde longitudinale effect vinden, onderstreept het belang van flexibele arbeidsvoorwaarden voor de gewenste pensioenleeftijd van oudere werknemers.

Het huidige onderzoek biedt ondanks deze kanttekeningen waardevol inzicht in de effecten van arbeidsvoorwaarden op langer doorwerken. De huidige studie laat zien dat arbeidsvoorwaarden die te maken hebben met flexibiliteit van belang zijn bij het willen doorwerken of vroegtijdig stoppen. Hoe hoger de tevredenheid van werknemers met deze arbeidsvoorwaarden, hoe langer zij willen doorwerken. Dit biedt de werkgever de mogelijkheid werknemers te stimuleren om langer door te werken. 


\section{Praktijkbox}

Wat betekenen de resultaten voor de praktijk?

- Door de flexibiliteit in het werk (zoals mogelijkheden tot deeltijdwerk, flexibele werktijden en thuiswerkregeling) naar tevredenheid van de werknemer in te vullen zullen oudere werknemers langer willen doorwerken.

- Het naar tevredenheid invullen van flexibiliteit kan alleen als het in samenspraak met werknemers plaatsvindt en wordt afgestemd op individuele wensen.

\section{Literatuur}

Actuarieel Genootschap en Actuarieel Instituut. (2010). Prognosetafel 2010-2060. Utrecht.

Armstrong-Stassen, M. (2008) Organisational practices and the post-retirement employment experience of older workers Human Resource Management Journal, 18, 36-53.

Baltes, P.B., Staudinger, U.M. \& Lindenberger, U. (1999). Life-span psychology: Theory and application to intellectual functioning. Annual Review of Psychology, 50, 471-507.

Cohen, J. \& Cohen, P. (1983). Applied multiple regression/correlation analysis for the behavioral sciences (2nd edition). Hillsdale, NJ: Erlbaum.

De Boer, A., Broese van Groenou, M. \& Timmermans, J. (2009). Mantelzorg; een overzicht van de steun van en aan mantelzorgers in 2007 (SCP-publicatie 2009/5). Den Haag: Sociaal en Cultureel Planbureau.

Deci, E.L. (1971). Effects of externally mediated reward on intrinsic motivation. Journal of Personality and Social Psychology, 18, 105-115.

European Commission (2008). Demographic Trends, Socio-Economic Impacts and Policy Implications in the European Union - 2007. Directorate-General "Employment, Social Affairs and Equal Opportunities" Unit E1 - Social and Demographic Analysis.

Eurostat (2008). Europe in figure: Eurostat Yearbook 2008. Luxemburg: Eurostat European Commission.

Henkens, K. \& Tazelaar, F. (1997). Explaining Retirement Decisions of Civil Servants in the Netherlands. Intentions, Behavior, and the Discrepancy between the Two. Research on Aging, 19, 139-173.

Henkens, K., Van Dalen, H. \& Van Solinge, H. (2009). De vervagende grens tussen werk en pensioen. Over doorwerken, doorstarten en herintreders. Den Haag: NIDI.

Henkens, K. \& Van Solinge, H. (2003). Het eindspel: werknemers, hun partners en leidinggevenden over uittreden uit het arbeidsproces. Assen: Van Gorcum.

Ilardi, B.C., Leone, D., Kasser, R. \& Ryan, R.M. (1993). Employee and supervisor ratings of motivation: Main effects and discrepancies associated with job satisfaction and adjustment in a factory setting. Journal of Applied Social Psychology, 23, 1789-1805.

Kaiser, H.F. (1960). The application of electronic computers to factor analysis. Educational and Psychological Measurement, 20, 141-151.

Kooij, T.A.M., Jansen, P.G.W., Dikkers, J.S.E. \& De Lange, A.H. (2009). Retaining older workers: Using a case study to formulate propositions on the role of HR bundles. Best Paper Proceedings of the Academy of Management Annual Meeting, Chicago.

Koppes, L., De Vroome, E. \& Van den Bossche, S. (in bewerking). NEA-cohortonderzoek: Methodologie en globale resultaten. 
Remery, C., Henkens, K., Schippers, J. \& Ekamper, P. (2003. Managing an aging workforce and a tight labor market: Views held by Dutch employers. Population Research and Policy Review, 22, 21-40.

Smulders, P.G.W., Andries, F. \& Otten, F. (2001). Hoe denken Nederlanders over hun werk? Opzet, kwaliteit en eerste resultaten van de TNO Arbeidssituatie Survey. Hoofddorp: TNO Arbeid.

Ten Have, C.J.M., Oeij, P.R.A. \& Kraan, K.O. (2007). Arbeidsvoorwaarden en arbeidsverhoudingen op ondernemingsniveau. Hoofddorp: TNO.

Uberla, K. (1971). Faktorenanalyse. Berlin/Heidelberg/New York: Springer.

United Nations (2007). World economic and social survey 2007: Development in an ageing world. New York: United Nations. Department of economic and social affairs.

Van Dam, K., Van der Vorst, J.D.M. \& Van der Heijden, B.I.J.M. (2009). Employees' intentions to retire early. A case of planned behavior and anticipated work conditions. Journal of Career Development, 35, 265-289.

Van den Berg, T.I., Elders, L.A. \& Burdorf, A. (2010). Influence of health and work on early retirement. Journal of Occupational \& Environmental Medicine, 52, 576-583.

Van den Bossche, S.N.J., Koppes, L.L.J., Granzier, J.J.M., De Vroome, E.M.M. \& Smulders, P.G.W. (2008). Nationale enquête arbeidsomstandigheden 2007: Methodologie en globale resultaten. Hoofddorp: TNO.

Van den Broeck, A., Vansteenkiste, M., De Witte, H., Lens, W. \& Andriessen, M. (2009). De zelf-determinatie theorie: Kwalitatief goed motiveren op de werkvloer. Gedrag \& Organisatie, 22, 316-335.

Van der Boom, E. \& Adams, F. (2006). Werkt grijs door? Tweede meting attitude en gedrag onder de potentiële beroepsbevolking en werkgevers ten aanzien van de arbeidsparticipatie van ouderen. Rotterdam: Ecorys Nederland BV.

Van Duin, C. \& Garssen, J. (2010). Bevolkingsprognose 2010-2060: sterkere vergrijzing, langere levensduur. Den Haag/Heerlen: CBS.

Vansteenkiste, M., Neyrinck, B., Niemiec, C.P., Soenens, B., De Witte, H. \& Van Den Broeck, A. (2007). On the relations among work value orientations, psychological need satisfaction, and job outcomes: A self-determination theory approach. Journal of Occupational and Organizational Psychology, 80, 251-277.

Ybema, J.F., Geuskens, G. \& Oude Hengel, K. (2009). Oudere werknemers en langer doorwerken: Secundaire analyses van de NEA, het NEA-cohortonderzoek en de WEA. Hoofddorp: TNO.

\section{Terms of employment and the preferred retirement age}

M.H.J. van Zwieten, J.F. Ybema \& G. Geuskens, Gedrag \& Organisatie, volume 24, November 2011, $n$ r. 4, pp 410-427.

The present study examines how the satisfaction with the terms of employment among older employees affects the preferred retirement age. Two waves of data collection (2008 and 2009) of the cohort-study of the Netherlands Working Conditions Survey (NWCS) were used for this study. The results of this longitudinal study showed that satisfaction with terms of employment that concern flexibility (e.g. flexible working hours and the possibilities for part-time work) contribute to a higher preferred retirement age. It also contributes to not specifying the preferred retirement age. This means that employees who are satisfied with the flexibi- 
lity in their jobs more often do not know at what age they prefer to retire than employees who are not satisfied, but if they do know they report a higher preferred retirement age. By arranging flexibility in the job together with and to the satisfaction of employees, employees can be stimulated to postpone retirement.

Key words: terms of employment, retirement age, longitudinal research 